\title{
Temporal and spatial variation in the diet of a marine top predator-links with commercial fisheries
}

\author{
Stephen C. Votier $^{1, *}$, Stuart Bearhop ${ }^{2}$, Ralph Fyfe ${ }^{3}$, Robert W. Furness ${ }^{4}$ \\ ${ }^{1}$ Marine Biology \& Ecology Research Centre, School of Biological Sciences, University of Plymouth, Plymouth PL4 8AA, UK \\ ${ }^{2}$ Centre for Ecology \& Conservation, School of Biosciences, University of Exeter, Cornwall Campus, Penryn, \\ Cornwall TR10 9EZ, UK \\ ${ }^{3}$ School of Geography, University of Plymouth, Plymouth PL4 8AA, UK \\ ${ }^{4}$ Institute of Biomedical and Life Sciences, Graham Kerr Building, University of Glasgow, Glasgow G12 8QQ, UK
}

\begin{abstract}
The huge quantities of waste produced by commercial fisheries worldwide attract large numbers of scavengers. Reducing this wasteful practice is desirable, but may have implications for marine ecosystems as scavengers will face a major shortfall in food. Predicting the impact of reduced discarding requires information on the strength of the link between scavengers and fisheries. We analysed sagittal otoliths regurgitated by great skuas Stercorarius skua over 5 yr from 8 different colonies in Shetland, UK, and over 18 yr from 1 of these sites, in relation to spatial and temporal variation in fisheries activity. The proportions of 2 demersal fish not normally available to skuas, haddock Melanogrammus aeglefinus and whiting Merlangius merlangus, are positively correlated with annual variation in discard estimates. The proportion of whiting at 8 colonies is positively correlated with spatial differences in fish biomass estimates, and blue whiting Micromesistus potassou are only eaten in colonies close to the continental shelf edge, where this species is fished. Non-breeding great skuas tend to eat smaller and significantly more variable discarded fish compared with breeders. Our results indicate that great skuas rely heavily on fishery discards and are also sensitive to spatial and temporal changes in fisheries activity. Differences between breeding status indicate that the nonbreeding component of the population may respond differently to changing discard policy. The strength of the link between fisheries and scavengers appear to be species-specific, and testing the strength of these relationships should be an important avenue of future research to interpret the response of scavengers to changes in fisheries management.
\end{abstract}

KEY WORDS: Fisheries $\cdot$ Discards $\cdot$ Seabirds $\cdot$ Diet $\cdot$ Scavenger $\cdot$ Foraging

\section{INTRODUCTION}

Commercial capture fisheries are a feature of virtually all marine ecosystems and, although understanding their impact is extremely challenging, it is clear that current exploitation levels are unsustainable in many fisheries (Pauly et al. 2002). Commercial fisheries, especially bottom-trawl fisheries, typically return large quantities of dead or damaged fish back to the sea in the form of discards, a practice which further inhibits sustainability. However, increased selectivity of gear, changes in management policy, declining quo- tas and diminishing catches have recently led to a reduction in discards (Zeller \& Pauly 2005). While this reduction is highly desirable, it may have unfortunate consequences for the large number of animals that utilise fishery waste.

Although a wide range of taxa scavenge waste from commercial fisheries (King et al. 2007), seabirds are the most conspicuous, and it is now apparent that this resource is important to many seabirds in shelf areas around the world (Furness 2003, Furness et al. 2007). As well as being linked with increases in some scavenger populations (Mitchell et al. 2004), discard avail- 
ability has also been shown to directly influence aspects of seabird breeding (Oro et al. 1996), overwinter condition (Hüppop \& Wurm 2000) and demography (Oro \& Pradel 2000). Global-scale declines in discard availability may leave artificially inflated populations of scavenging seabirds short of food, which has profound implications for aquatic food web dynamics, as well as conservation and ecosystem management (Regehr \& Montevecchi 1997, Stenhouse \& Montevecchi 1999, Votier et al. 2004a). Thus, it is imperative that we gain a better understanding of the impact of changes in discarding rates for seabird communities.

Regardless of the evidence that seabirds scavenge extensively for discards, our grasp of the ways in which they interact with fisheries is still limited. For instance, despite the evidence that fisheries closure or moratoria can have an impact on aspects of seabird ecology (Oro et al. 1996, Hüppop \& Wurm 2000), other studies indicate that natural foods may be more important than discards to scavenging species. Although northern gannets Morus bassanus show a strong association with fishing vessels in the North Sea during winter, they do not in summer (Tasker et al. 1985) and have also been shown to ignore fishing boats when feeding for herring Clupea harengus during the breeding season (Camphuysen et al. 1995). The distribution of 5 species of seabird in the Baltic Sea and North Sea was more strongly influenced by oceanographic features than the distribution of trawlers (Skov \& Durinck 2001). Moreover, Camphuysen \& Garthe (1997) estimated that for northern fulmars Fulmarus glacialis in the North Sea, less than $50 \%$ of their energy requirement was met by offal and discards. Therefore, the strength of the link between seabirds and commercial fishing activities is not entirely clear, which has implications for assessing the possible impact of future change.

The aim of the present study was to provide a measure of discard consumption by a marine top predator (the great skua Stercorarius skua) in relation to temporal and spatial variation in fisheries activity in the North Sea. Great skua numbers have increased greatly since 1900, and their ability to feed facultatively on fisheries waste is believed to be an important factor in this change. As well as affecting skuas directly, declining discards may have implications for other seabirds. Years of low discards and reductions in availability of their other main prey, sandeels Ammodytes marinus, has led to increased predation on some smaller seabirds (Votier et al. 2004a), leading to adverse effects on the population dynamics of seabird prey species (Votier et al. 2008). We compared otoliths collected from pellets regurgitated by great skuas at 8 breeding colonies in Shetland, UK, over $5 \mathrm{yr}$, with fish biomass estimates disaggregated by area, to investigate whether these central place foragers consume discards in relation to their local availability and whether there is evidence of selectivity. Discards from the trawl fishery in the northwest North Sea are mainly of haddock Melanogrammus aeglefinus and whiting Merlangius merlangus, species that are not normally available as prey for skuas because they remain close to the seabed, whereas skuas can only catch fish in the top 1 or $2 \mathrm{~m}$ of the sea. Size classes of fish eaten by skuas were estimated from otolith sizes and compared with the minimum landing size (the smallest size at which it is legal to land a fish), where one exists. This provides information on the type of discards taken by skuas: either undersized catch, large fish discarded because of exceeding quotas, or high grading (selectively sorting the best components of the catch) by fishermen. In addition, we investigated whether the incidence of the 2 predominant discarded fish species in the diet (haddock and whiting) is correlated with temporal variation in discard estimates over $17 \mathrm{yr}$ (1988 to 2004). Moreover, given that non-breeding birds form an important component of the population at colonies (Klomp \& Furness 1992) and that other studies have indicated differences between the diets of breeders and non-breeders (Votier et al. 2004b), we also compared discard use between these 2 age classes. Experience-related differences in foraging efficiency may mean breeders scavenge more effectively than non-breeders, which could have consequences for the effects of changes in discard availability. By determining how closely linked great skuas are with commercial fisheries when foraging from a central place (as breeders, at least), will provide an indication of the sensitivity of this marine top predator to changes in discarding policy.

\section{MATERIALS AND METHODS}

Study sites. Data were collected from 8 breeding colonies of great skuas in Shetland, UK: Foula $\left(60^{\circ} 08^{\prime} \mathrm{N}\right.$, $\left.2^{\circ} 05^{\prime} \mathrm{W}\right)$, Hermaness, Unst $\left(60^{\circ} 50^{\prime} \mathrm{N}, 1^{\circ} 12^{\prime} \mathrm{W}\right)$, Lamb Hoga, Fetlar $\left(60^{\circ} 38^{\prime} \mathrm{N}, 0^{\circ} 54^{\prime} \mathrm{W}\right)$, Lumbister, Yell $\left(60^{\circ} 39^{\prime} \mathrm{N}, 1^{\circ} 06^{\prime} \mathrm{W}\right)$, Noss $\left(60^{\circ} 08^{\prime} \mathrm{N}, 1^{\circ} 00^{\prime} \mathrm{W}\right)$, Noss Hill $\left(59^{\circ} 55^{\prime} \mathrm{N}, 1^{\circ} 21^{\prime} \mathrm{W}\right)$, Fair Isle $\left(59^{\circ} 32^{\prime} \mathrm{N}, 1^{\circ} 38^{\prime} \mathrm{W}\right)$ and Noness $\left(60^{\circ} 42^{\prime} \mathrm{N}, 1^{\circ} 16^{\prime} \mathrm{W}\right)$ (Fig. 1).

Diet. To provide information on spatial use of fishery discards, we analysed the contents of regurgitated pellets of indigestible material collected from great skua breeding territories throughout June and July in 1996, 1998, 1999, 2000 and 2003. All colonies were visited at least once although not all colonies were sampled in all years (see Table 1). Sagittal otoliths were removed from pellets and stored dry for subsequent identification using Härkönen (1986) and measured to the nearest mm. Although otoliths may erode in the gut for large white- 


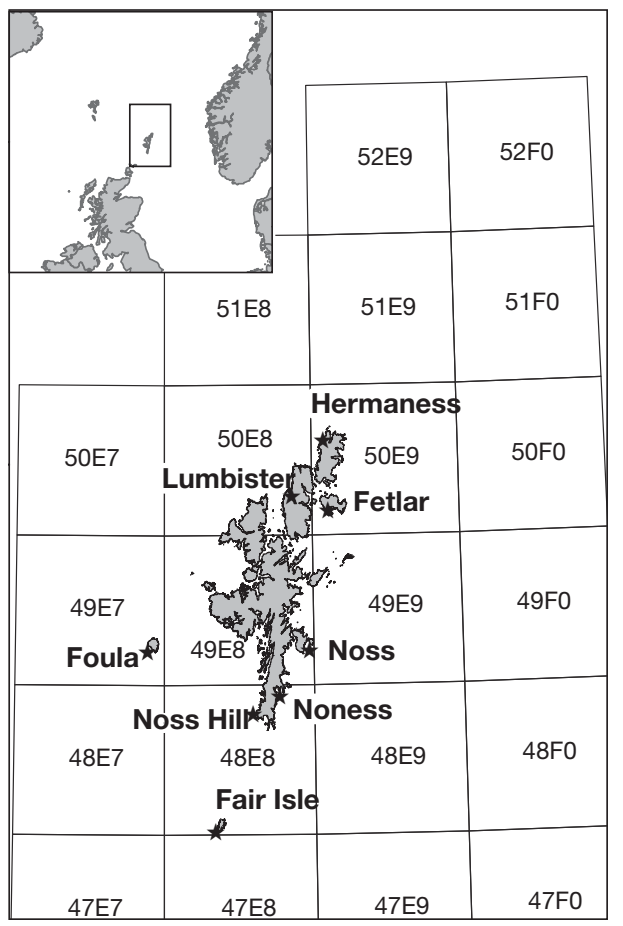

Fig. 1. Shetland, UK, $(\star)$ great skua colonies sampled in the present study and ICES-FishMap grids

fish, this difference is negligible in skua pellets which are cast relatively soon after the fish has been eaten (Votier et al. 2001). We calculated fish lengths from otolith lengths using equations in Furness \& Hislop (1981) and Härkönen (1986).

To obtain a more detailed assessment of temporal trends in relation to changes in discarding rates, we analysed the diet of breeding skuas in the same way on Foula each June and July 1988 through 2004. We also compared the diet of breeding and non-breeding skuas for the same period. Non-breeders gather at tra- ditional 'clubs' in and around the colony between May and August, where breeders are scarce (Klomp \& Furness 1992).

Fish biomass estimates. We extracted spatial data on fish biomass estimates from ICES (International Council for the Exploration of the Sea)-FishMap, www.ices. $\mathrm{dk} / \mathrm{marineworld/ices-fishmap.asp,} \mathrm{an} \mathrm{online} \mathrm{electronic}$ atlas of 15 North Sea fish species based on data collected by research vessels. These data were plotted using ArcGIS 9.2, and from these plots we estimated the quantities of fish caught within circles of a radius $30 \mathrm{~km}$ from each colony. This area covers the approximate foraging range of a centrally placed great skua in the breeding season (Votier et al. 2004c). ICESFishMap does not include data on blue whiting Micromesistus potassou, so we used data from Knijn et al. (1993) for the years 1985 to 1987. Although this represents a different time period from that of skua diet sampling, the data reflect the ecology of this species, which occurs in deep waters off the continental shelf.

In addition, we obtained annual discard estimates from the commercial fleet for haddock and whiting in ICES sub-area IVa in the northwestern North Sea (ICES 2005, www.ices.dk/aboutus/icesareas.asp). We compared these discard estimates with the proportion of these 2 fish present in the diet of breeding great skuas on Foula during 1988 through 2004.

Statistical analysis. Although paired in whole fish, the primary sampling unit throughout the present study was a single sagittal otolith.

To examine the interactive effect of colony and year on the consumption of the 5 main fish types (Norway pout Trisopterus esmarki, haddock, whiting, blue whiting and other fish; Table 1) we used logit loglinear (or multinomial logit) models. These function as multidimensional contingency tables, and to allow for incomplete colony sampling in all years, we defined structural zeros for empty cells.

Table 1. Stercorarius skua. Percentage number of fish otoliths in pellets regurgitated by breeding great skuas at 8 colonies in Shetland during June and July 1996, 1998, 1999, 2000 and 2003. All fish are identified from sagital otoliths recovered from pellets of indigestible material, values in \%. Total: total number of otoliths sampled in each year at each colony. Lumb: Lumbister

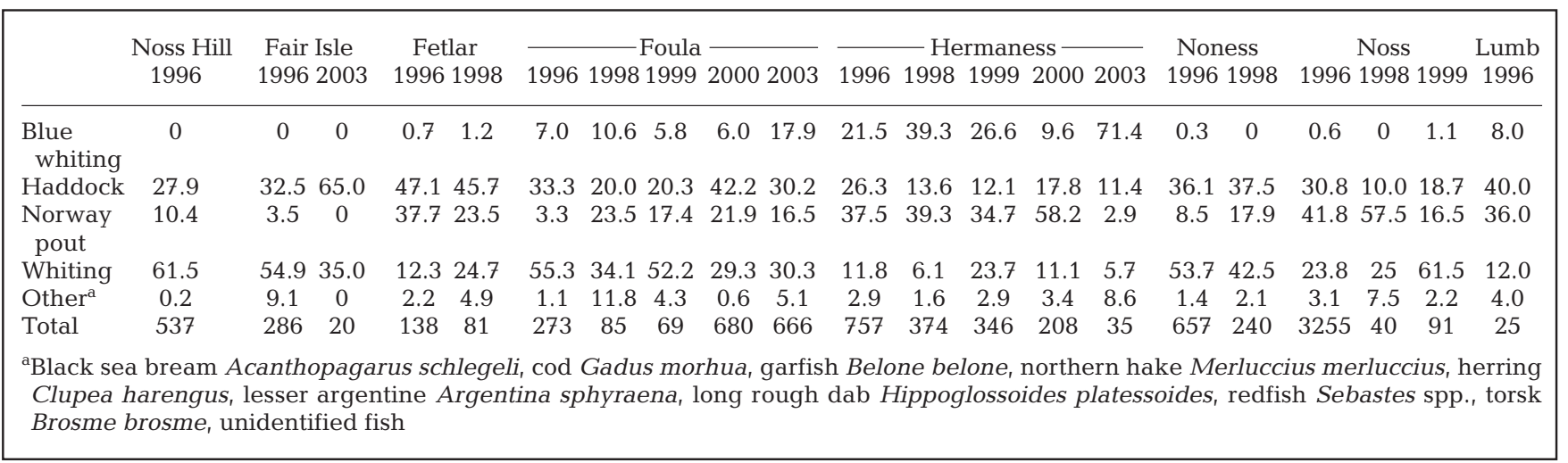


We compared the spatial distribution of ICES fish biomass estimates with fish consumption by great skuas at different colonies using Generalized Linear Mixed Models. Because of the non-orthogonal sampling design, we used residual maximum likelihood (REML) models. The number of fish otoliths was the dependent variable and total number of otoliths the binomial denominator. The amount of fish (log transformed to normalize) within a circle of radius $30 \mathrm{~km}$ and year were included as fixed factors, and colony as a random factor.

Annual variation in the consumption of discards by skuas may be related to annual variation in the amount discarded by fisheries. We compared annual discard estimates of whiting and haddock in ICES sub-area IVa with the number of otoliths recovered from regurgitated pellets of breeding great skuas on Foula over the period 1988 through 2004 using logistic regression. The number of whiting or haddock otoliths was the response variable and the total number of pellets included as a binomial denominator. We used the binomial family of models for fitting, including quasibinomial models to account for over dispersion.

We investigated whether the proportion of each fish species consumed by breeders and non-breeders was statistically more correlated than expected by chance by calculating Euclidean distances for all pairwise (Spearman's rank) correlations of fish types consumed by breeders and non-breeders. In addition we compared the average size and variation in size of fish recovered from skua pellets between breeders and non-breeders using $t$-tests (assuming unequal variances where appropriate) and Levene's test for homogeneity of variances, respectively.

We used SPPS 15.0, Genstat 10 and R v.2.5.1 (R Development Core Team 2007) for the analysis.

\section{RESULTS}

\section{Fish consumed by great skuas}

The discard fish component of great skua diets was dominated by 4 main species: Norway pout, haddock, whiting and blue whiting (Table 1). Each of these species is landed commercially and is characterized by demersal or benthopelagic lifestyles, thereby occurring at depths outside the known diving range of great skuas. At least 9 other fish species were identified from otoliths, including a mixture of benthic and pelagic and commercial and non-commercial species (Table 1).

The sizes of fish eaten by great skuas on Foula (1988 to 2004), as well as the minimum landing size (where applicable), are shown in Fig. 2. Virtually all haddock consumed were smaller than the current minimum

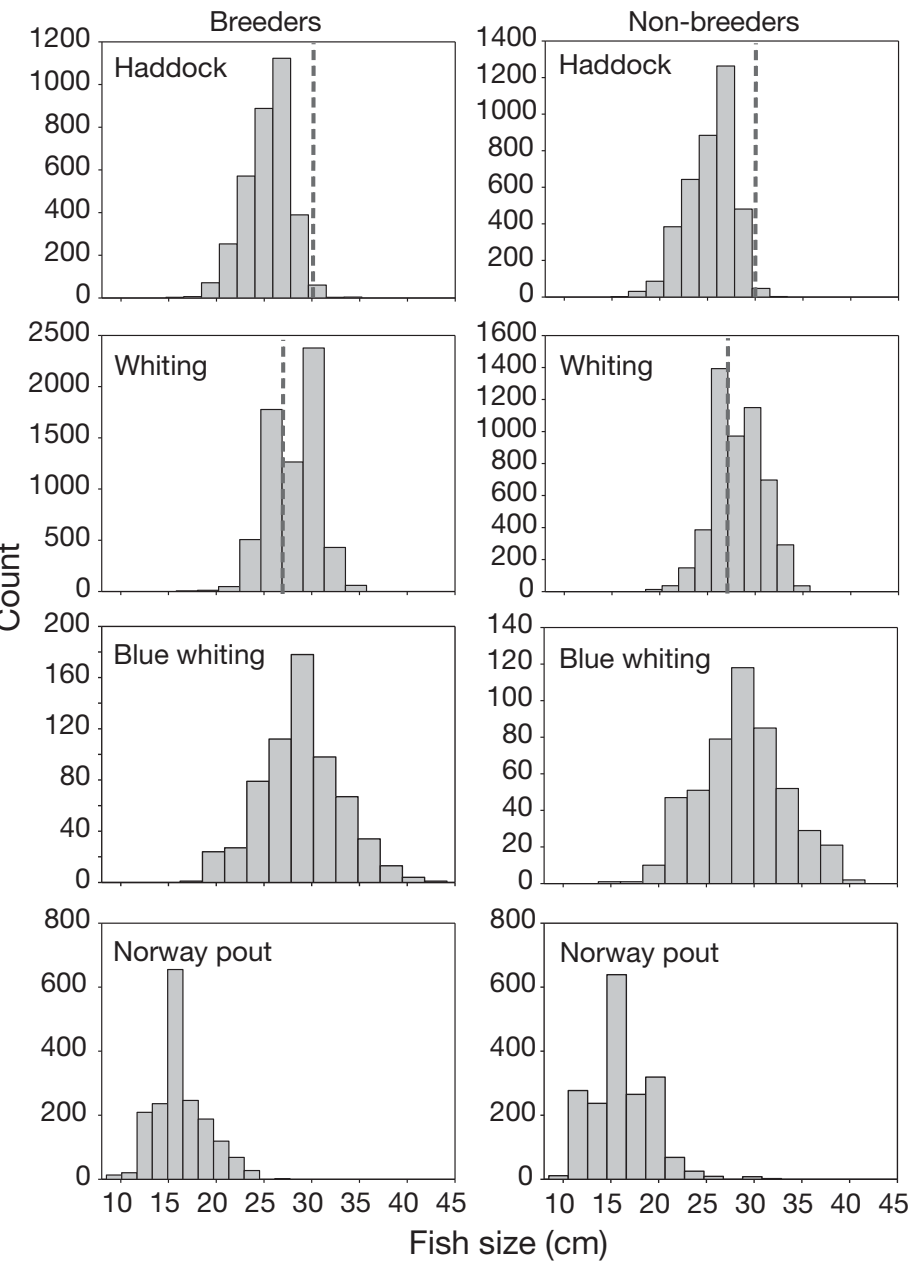

Fig. 2. Stercorarius skua. Frequency distribution of sizes for 4 fish species found in the diet of great skuas on Foula, Shetland, 1988 through 2004. Dashed lines: the minimum landing size for haddock and whiting in the North Sea. Blue whiting and Norway pout do not have a minimum landing size

landing size of $30 \mathrm{~cm}$, whereas the majority of whiting were larger than the current minimum landing size $(27 \mathrm{~cm})$. The average size of blue whiting was ca. 27 $\mathrm{cm}$ and $15 \mathrm{~cm}$ for Norway pout.

\section{Inter-colony variation in fish consumption}

There was pronounced variation in the proportions of different species of discarded fish in regurgitated pellets among year and colony (Table 1). The best fitting multinomial logit model included year and colony main effects (Pearson $\chi^{2}=163.994$, df $=36, \mathrm{p}<0.001$ ), which was significantly better supported than the constant model or a model including a 2-way interaction. Therefore the proportion of the 5 main fish types differed significantly among year and colony, and colony differences remained consistent across years. 


\section{Inter-colony variation in relation to fish biomass estimates}

The distribution of 4 species caught commercially in Shetland waters varied spatially and temporally, as did the fish component of skua diets (Fig. 3). REMLs revealed that the amount of whiting caught within $30 \mathrm{~km}$ of focal colonies varied among years and was significantly positively correlated with the proportion in the diet of great skuas (Table 2). There was no significant effect of catch statistics or year on the proportion of Norway pout or haddock in great skua diets (Table 2). It was not possible to conduct the same analysis for blue whiting, but this species is found in deep waters off the continental shelf (as evidenced by the data from 1985 to 1987), and this is reflected in the almost complete absence of this species in the south and east of Shetland (Fig. 3).

\section{Annual variation in relation to discard estimates}

Inter-annual variation in consumption of haddock and whiting by breeding great skuas on Foula was significantly positively correlated with discard estimates in the region (Table 3, Fig. 4).

\section{Fish consumption by breeding and non-breeding great skuas}

Breeding and non-breeding great skuas had diets dominated by the same species of fish (Fig. 5). Although the 2 classes showed differences in the proportions of each type of fish consumed (Fig. 5), multi-

Table 2. Relationship between proportion of 3 fish species found in the pellets of breeding great skuas at 8 colonies over $5 \mathrm{yr}$ and ICES fish biomass estimates disaggregated by area. Model parameter estimates are based on residual maximum likelihood (REMLs). (Log) Catch within $30 \mathrm{~km}$

\begin{tabular}{|lccccc|}
\hline Model term & Wald & df & $\mathrm{p}$ & Estimate & $\mathrm{SE}$ \\
\hline Whiting & & & & & \\
Intercept & & & & -0.627 & 0.256 \\
(Log) Catch & 40.77 & 1 & $<0.001$ & 0.902 & 0.144 \\
Year & 19.02 & 4 & 0.033 & 0.0328 & 0.275 \\
Haddock & & & & & \\
Intercept & & & & -0.533 & 0.272 \\
(Log) Catch & 0.30 & 1 & 0.592 & 0.010 & 0.202 \\
Year & 9.60 & 4 & 0.136 & -0.403 & 0.328 \\
Norway pout & & & & & \\
Intercept & & & & -0.850 & 0.525 \\
(Log) Catch & 2.37 & 1 & 0.161 & 0.116 & 0.167 \\
Year & 0.95 & 4 & 0.907 & -0.445 & 0.470 \\
\hline
\end{tabular}

Table 3. Annual variation in fish consumption by breeding great skuas on Foula, Shetland, (1988 through 2004) in relation to annual variation in discard estimates in ICES sub-area IVa. Model outputs are from logistic regression models with binomial error distribution

\begin{tabular}{|lcccrc|}
\hline Model term & \multirow{2}{*}{$t$} & $\mathrm{df}$ & $\mathrm{p}$ & Estimate & $\mathrm{SE}$ \\
\hline Haddock & & & & & \\
Intercept & & & & -2.290 & 0.482 \\
Discards & 2.864 & 1 & 0.01 & 0.023 & 0.008 \\
Whiting & & & & & \\
Intercept & & & & -1.388 & 0.457 \\
Discards & \multirow{2}{*}{3.332} & 1 & 0.005 & 0.047 & 0.014 \\
\hline
\end{tabular}

variate similarity matrices were highly significantly correlated (Spearman's rho $=0.781, \mathrm{p}<0.001$ ), indicating that breeders and non-breeders had broadly similar diets across years.

The sizes of the 4 main fish species (Norway pout, haddock, whiting and blue whiting) eaten by breeding and non-breeding great skuas on Foula during 1988 through 2004 are shown in Fig. 2. Breeding great skuas consumed larger and less variable haddock $($ Mean \pm SD $25.522 \pm 2.624 \mathrm{~cm}$ ) compared with nonbreeders $(25.362 \pm 2.770 \mathrm{~cm}$ : Levene's test for homogeneity of variances, $F_{1,7195}=13.144, \mathrm{p}<0.001 ; t$-test with unequal variances, $t_{7157.8}=2.503, p=0.012$ ). Similarly, significantly larger and significantly less variable whiting were eaten by breeders (28.446 \pm $2.706 \mathrm{~cm}$ ) compared with non-breeders (28.223 \pm $2.760 \mathrm{~cm}$ : Levene's test for homogeneity of variances, $F_{1,11612}=8.474, \mathrm{p}=0.004 ; t$-test with unequal variances, $\left.t_{10902.6}=4.361, \mathrm{p}<0.001\right)$. The size and variability of blue whiting consumed was not significantly different between breeders $(28.759 \pm 4.604 \mathrm{~cm})$ and non-breeders $(28.898 \pm 4.930 \mathrm{~cm}$ : Levene's test for homogeneity of variances, $F_{1,1128}=3.788, \mathrm{p}=0.052 ; t$-test with equal variances, $t_{1128}=-0.485, \mathrm{p}=0.627$ ), whereas nonbreeders consumed more variable, but similar-sized, Norway pout $(16.130 \pm 3.029 \mathrm{~cm})$ compared with breeders $(16.092 \pm 2.753 \mathrm{~cm}$ : Levene's test for homogeneity of variances, $F_{1,3642}=4.938, \mathrm{p}=0.026$; $t$-test with unequal variances, $\left.t_{3632.1}=-0.396, p=0.692\right)$.

\section{DISCUSSION}

\section{Fish consumption}

Analysis of sagittal otoliths from regurgitated pellets revealed a predominance of 4 demersal or benthopelagic fish; Norway pout, haddock, whiting and blue whiting, species which are beyond the normal foraging depth of great skuas. Together with observations of 

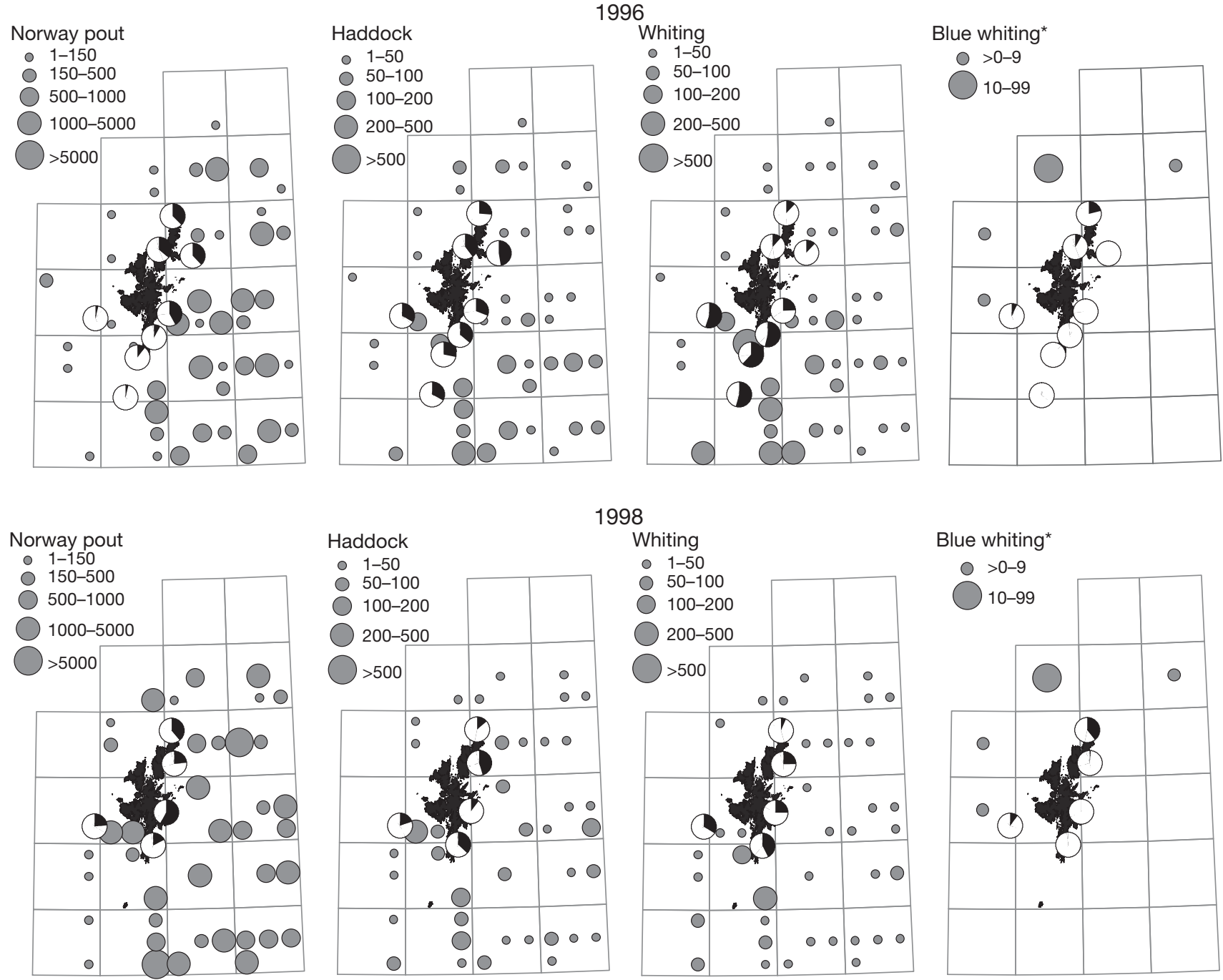

1998

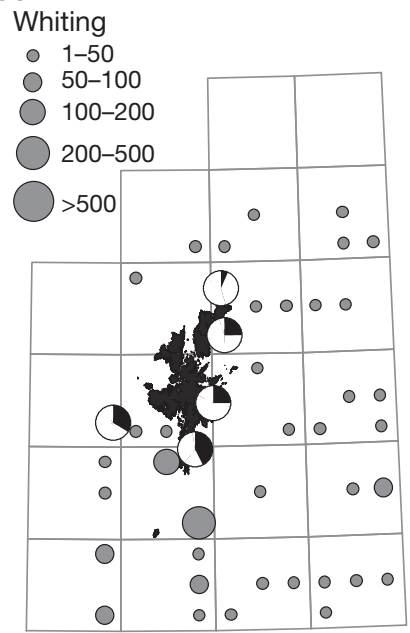

Blue whiting*
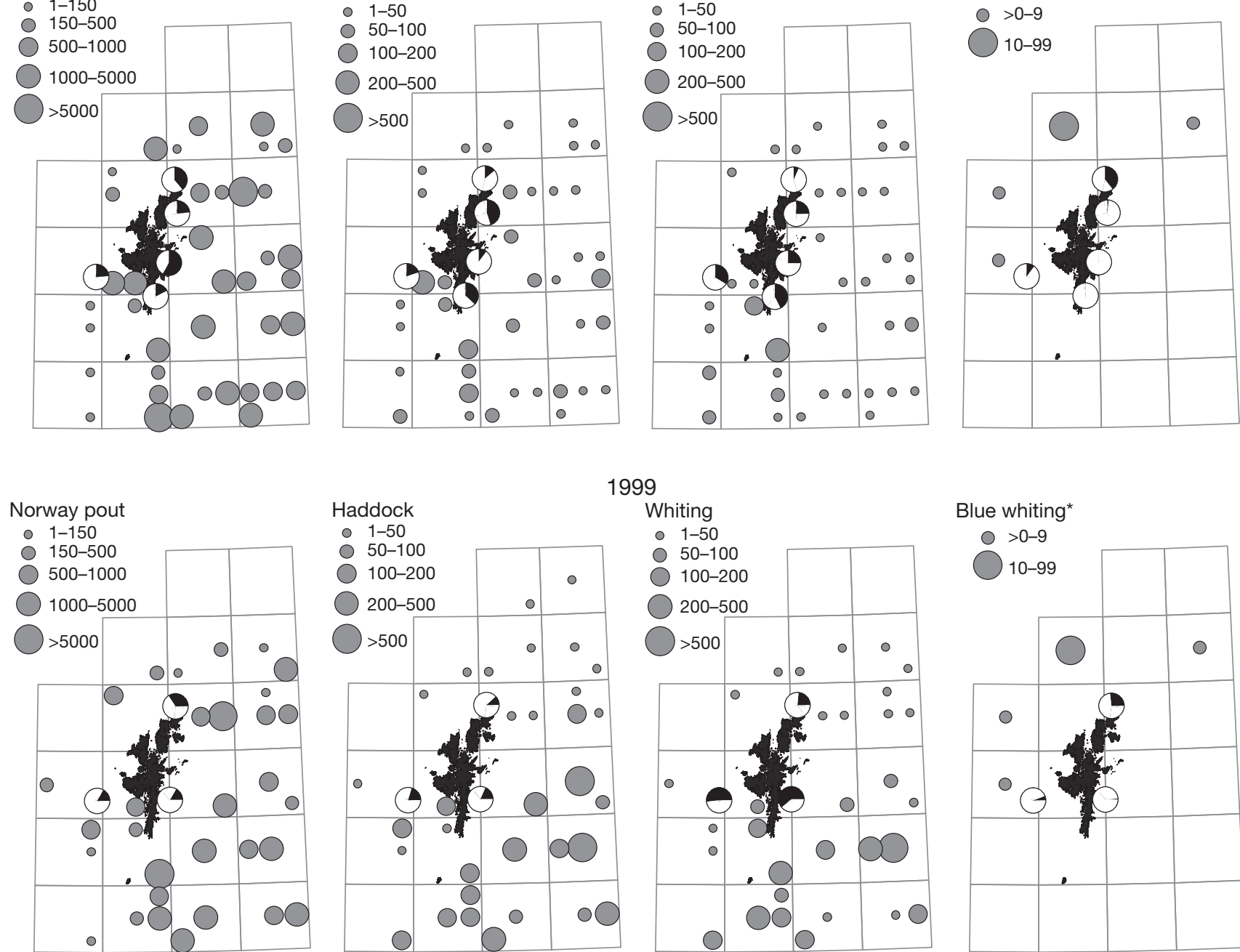

1999
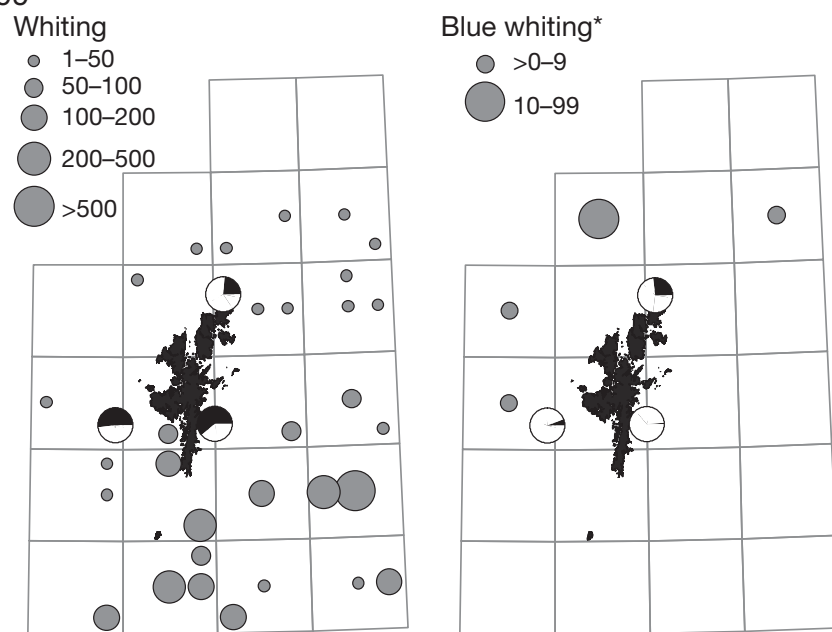

Fig. 3. (Above and facing page.) Fish biomass estimates of Norway pout, haddock, whiting and blue whiting in Shetland waters (filled circles) and proportion of otoliths in great skua Stercorarius skua pellets (pie charts). Fisheries data are mean catch (no. $\mathrm{h}^{-1}$ ) per ICES sub-unit for respective years from ICES-FishMap, except blue whiting which is the average catch rate per hour of summer juveniles 1985 to 1987 (Knijn et al. 1993) 

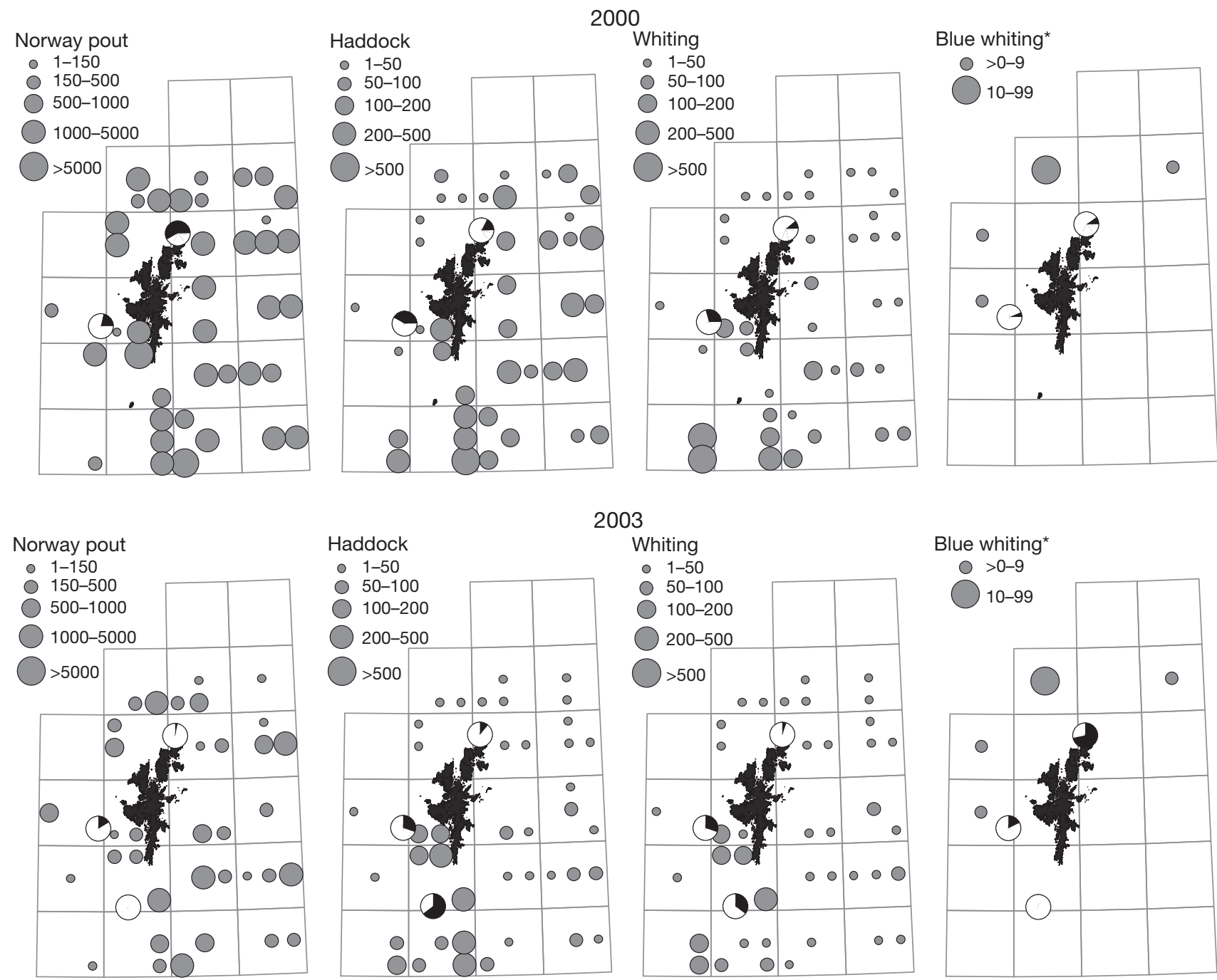

2003
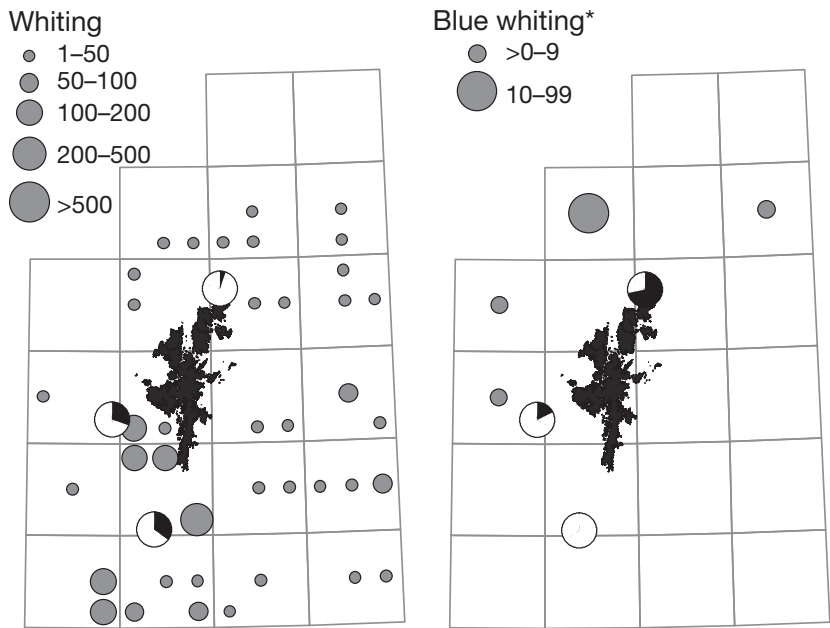

Fig. 3 (continued)

skuas associating with trawlers made from land (Bearhop et al. 2001), at sea (Hudson \& Furness 1989) and using radio-telemetry (Votier et al. 2004c), this is strong evidence that fishery discards are a key food resource for this marine top predator. Fish lengths calculated from otoliths indicate that great skuas eat haddock that are predominantly below, but close to, the minimum landing size of $30 \mathrm{~cm}$ (Fig. 2). These presumably represent undersized fish discarded from catches. In contrast, great skuas ate large quantities of whiting that were larger than the minimum landing size of $27 \mathrm{~cm}$ (Fig. 2). It is not clear whether these represent fish of a landable size caught in excess of quotas and discarded, or high grading by fishermen. Sizes of blue whiting average at ca. $27 \mathrm{~cm}$. This size class forms a significant proportion of commercially landed blue whiting (ICES 2005). The length composition of Norway pout in the North Sea shows peaks ca. 12 and $16 \mathrm{~cm}$ (ICES-FishMap). The $15 \mathrm{~cm}$ fish that predominate in skua diets are consistent with this peak of larger fish.

\section{Inter-colony variation in discard use}

There were significant differences in the proportion of the 5 main types of fish consumed by great skuas among the 8 colonies and $5 \mathrm{yr}$, but with no significant interactions (Tables 1 \& 2). Previous work has highlighted inter-colony differences in diet composition of great skuas (Phillips et al. 1997, Votier et al. 2007) which may relate to differences in the availability of the main prey (sandeels, discards and other birds), intra-specific competition or differences in foraging behaviour. A significant positive correlation between whiting otoliths in skua pellets and fish biomass esti- 

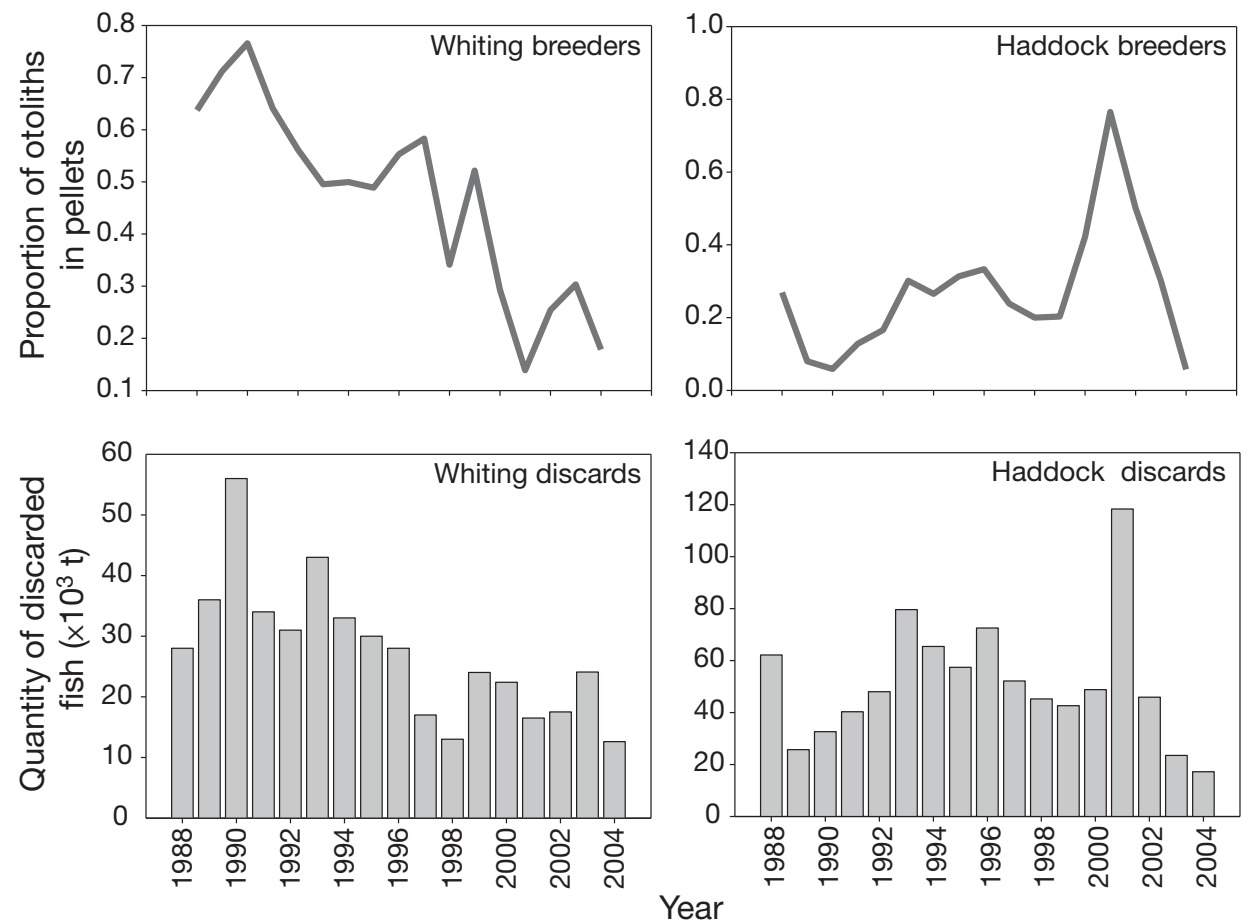

Fig. 4. Stercorarius skua. Variation in whiting and haddock consumption by breeding great skuas on Foula, Shetland, 1988 through 2004 in relation to changes in fishery discard rates in ICES sub-area IVa

mates (from ICES-FishMap) within $30 \mathrm{~km}$ of focal colonies indicates that, for this fish at least, intercolony variation in consumption relates to spatial differences in fishing catches, which presumably relates to differences in whiting availability. These patterns

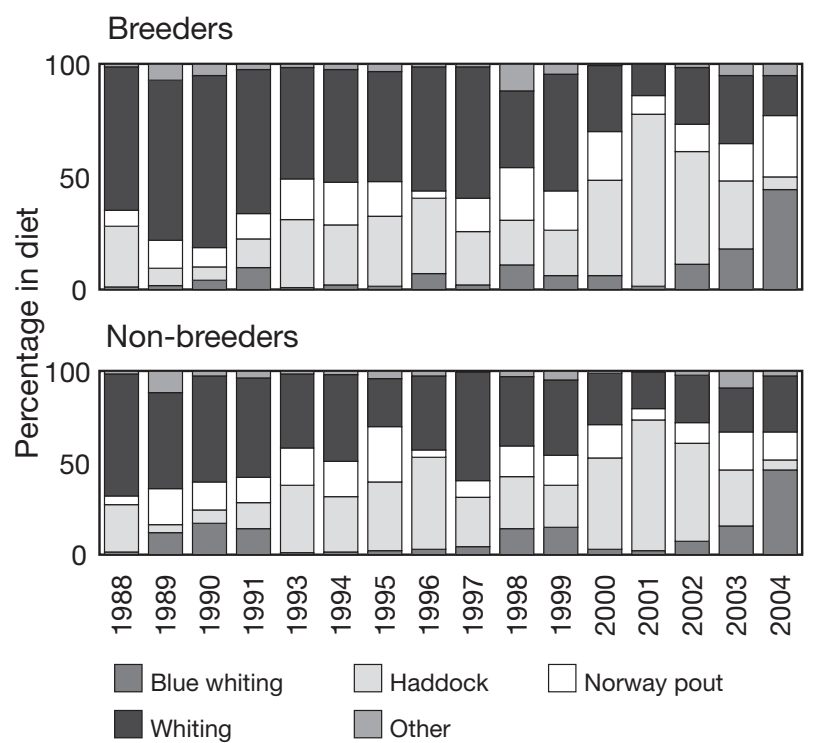

Fig. 5. Stercorarius skua. Comparing fish in the diet of breeding and non-breeding great skuas on Foula, Shetland, during June and July 1988 through 2004 can in part be explained by consistently high catches of whiting in the south and west of Shetland and consistently low catches in the north and east (Fig. 3). Recent work at a much larger spatial scale indicates that hot spots of fishing activity are consistent over time (Witt \& Godley 2007), and this consistency may be important to scavenging seabirds, especially breeding adults constrained to forage from a central place. Spatial variation in the occurrence of blue whiting in skua diets is also consistent with catches of this fish. This species occurs in deep waters off the north and west of Shetland close to the continental shelf edge and, thus, is found only in the diet of great skuas from westerly and northerly colonies (Fig. 3). There were no significant relationships between the incidence of haddock and Norway pout in skua diets among colonies and catch statistics of these species. In the case of Norway pout, this species is used in fish meal production, and so the fishery rarely discards any fish. However, the trawl fishery for haddock and whiting takes Norway pout as a bycatch, and it seems more likely that skuas obtain this species from those vessels rather than from boats fishing for pout. Thus the distribution of discarded pout will bear no causal relation to the size or location of the directed pout fishery catch. It is not clear why spatial variation in haddock was not related to biomass estimates. 


\section{Annual variation in discard use}

There was a significant positive correlation between the proportion of haddock and whiting otoliths regurgitated by breeding great skuas on Foula and the quantity of these fish discarded in ICES sub-area IVa across years (Table 3, Fig. 4). This indicates that skuas are sensitive to changes in the availability of such discards. Previous work showed the same relationship for non-breeding great skuas on Foula during 1986 to 2002 (Votier et al. 2004a) and indicates the strong link between fishing activity and skua scavenging.

\section{Differences in discard use by breeders and non- breeders}

Although there were differences in the proportions of the fish species consumed by breeding and nonbreeding great skuas (Fig. 5), these age classes ate broadly similar fish species across years. The average and range of sizes of fish consumed were also very similar (Fig. 2), despite non-breeding great skuas consuming significantly smaller haddock and whiting compared with breeders. We would predict a priori that breeding birds would be able to take larger and less variable fish than non-breeders since foraging efficiency in birds is correlated with age (Wunderle 1991). Although average differences are small (see Results), it is apparent from the histograms (Fig. 2) that breeding skuas take a much larger number of whiting above the legal landing size compared with non-breeders. These differences indicate that breeding state and age (since non-breeding skuas tend to be younger than breeders) may have an impact upon responses to changes in discarding practice.

\section{Implications}

Our results (Fig. 4) suggest that, at current levels, the proportion of haddock and whiting discards in great skua diets is related to their resource availability. This indicates that discards are limited in some way: if they were not, we would not expect a relationship between discard availability and incidence in the diet of scavenging great skuas. This limitation may be because discarded fish quickly sink out of reach of great skuas or because of intra- and inter-specific competition with other scavengers. Consistently high catches of whiting in the south and west of Shetland and low catches in the north and east are correlated with the proportion of whiting eaten by great skuas (Fig. 3). Together with a tendency for blue whiting to occur in great skua diets close to deep water in the north and west of Shetland, great skuas respond to local scale differences in discards from fishing boats. The implications of these 2 results are that great skuas are not only reliant on discards, but are also sensitive to changes in fishing activity.

Differences in the size and range of fish taken by non-breeding great skuas provides some limited support for the notion that they are less effective competitors at trawls than breeders. However these differences are slight and it is not clear to what extent changes in discarding are likely to affect these different age classes.

Previous work has shown that for a number of opportunistic scavenging seabirds, at-sea distribution is better explained by spatial differences in natural food availability than the distribution of fishing vessels (Camphuysen et al. 1995, Skov \& Durinck 2001). Analysis of skua diets at colonies indicates a much closer association with fishing boats. It is not clear whether this difference is because of different foraging tactics of individual species or because of a fundamental difference in the way in which these 2 types of data have been collected. Our data were collected from breeding and non-breeding skuas which (to a variable extent) were foraging from a central place. This places a considerable time constraint on these birds, which may make trawlers a more attractive option than perhaps less predictable sources of food. The data collected by both Camphuysen et al. (1995) and Skov \& Durinck (2001) included birds of uncertain breeding status. Being freed from the constraints of central place foraging, these birds may have the time to target natural foods.

It seems clear from the data presented here that great skuas rely heavily on discarded fish, and are closely linked both spatially and temporally with commercial fisheries. As a consequence, future changes in discarding policy are likely to have important implications for this marine top predator. However the link between fisheries and scavengers may be strongly species-specific, and determining the strength of species-specific links should be an important avenue of future research to enable a more complete understanding of the impact of changes in fisheries management on seabird communities.

Acknowledgements. This work was funded by EU contract Q5RS-2001-00839 'DISCBIRD'. We thank J. Crane, P. Arcos, N. Ratcliffe, J. Stenning, R. King, J. Brown, M. Maher, C. Rodger and P. Harvey for help in the field, and A. Foggo helped with the multivariate statistics. Three referees made comments on an earlier draft.

\section{LITERATURE CITED}

Bearhop S, Thompson DR, Phillips RA, Waldron S and others (2001) Annual variation in great skua diets: the impor- 
tance of commercial fisheries and predation on seabirds revealed by combining dietary analyses. Condor 103: 802-809

> Camphuysen CJ, Garthe S (1997) An evaluation of the distribution and scavenging habits of northern fulmars (Fulmarus glacialis) in the North Sea. ICES J Mar Sci 54: 654-683

Camphuysen CJ, Heessen HJL, Winter CJN (1995) Distant feeding and associations with cetaceans of gannets Morus bassanus from the Bass Rock, May 1994. Seabird 17:36-43

Furness RW (2003) Impacts of fisheries on seabird communities. Sci Mar 67:33-45

Furness RW, Hislop JRG (1981) Diets and feeding ecology of great skuas Catharacta skua during the breeding season in Shetland. J Zool 195:1-23

Furness RW, Edwards AE, Oro D (2007) Influences of management practices and of scavenging seabirds on availability of fisheries discards to benthic scavengers. Mar Ecol Prog Ser 350:235-244

Härkönen T (1986) Guide to the otoliths of the bony fishes of the Northeast Atlantic. Danbiu ApS, Hellerup

Hudson AV, Furness RW (1989) The behaviour of seabirds foraging at fishing boats around Shetland. Ibis 131:225-237

Hüppop O, Wurm S (2000) Effects of winter fishery activities on resting numbers, food and body condition of large gulls Larus argentatus and L. marinus in the south-eastern North Sea. Mar Ecol Prog Ser 194:241-247

ICES 2005. Report of the working group on the assessment of demersal stocks in the North Sea and Skagerrak, 7-16 September 2004. ICES CM 2005/ACFM: 07

King NJ, Bailey DM, Priede IG, Browman HI (2007) Role of scavengers in marine ecosystems: Introduction. Mar Ecol Prog Ser 350:175-178

Klomp NI, Furness RW (1992) Nonbreeders as a buffer against environmental stress: declines in the numbers of great skuas on Foula, Shetland and prediction of future recruitment. J Appl Ecol 29:341-348

Knijn RJ, Boon TW, Heessen HJL, Hislop JRG (1993) Atlas of North Sea fishes: based on bottom-trawl survey data for the years 1985-1987. ICES Cooperative Research Report 194. ICES, Copenhagen

Mitchell PI, Newton SF, Ratcliffe N, Dunn TE 2004. Seabird populations of Britain and Ireland. T \& A D Poyser, London

Oro D, Pradel R (2000) Determinants of local recruitment in a growing colony of Audouin's gull. J Anim Ecol 69: 119-132

Oro D, Jover L, Ruiz X (1996) Influence of trawling activity on the breeding ecology of a threatened seabird, Audouin's gull Larus audouinii. Mar Ecol Prog Ser 139:19-29

Pauly D, Christensen V, Guénette S, Pitcher TJ and others

Editorial responsibility: Yves Cherel,

Villiers-en-Bois, France
(2002) Towards sustainability in world fisheries. Nature 418:689-695

Phillips RA, Catry P, Thompson DR, Hamer KC, Furness RW (1997) Inter-colony variation in diet and reproductive performance of great skuas Catharacta skua. Mar Ecol Prog Ser 152:285-293

R Development Core Team (2007). R: a language and environment for statistical computing. R Foundation for Statistical Computing, Vienna, available at: www.R-project.org

Regehr HM, Montevecchi WA (1997) Interactive effects of food shortage and predation on breeding failure of blacklegged kittiwakes: indirect effects of fisheries activities and implications for indicator species. Mar Ecol Prog Ser 155:249-260

Skov H, Durinck J (2001) Seabird attraction to fishing vessels is a local process. Mar Ecol Prog Ser 214:289-298

Stenhouse IJ, Montevecchi WA (1999) Indirect effects of the availability of capelin and fisheries discards: gull predation on breeding storm-petrels. Mar Ecol Prog Ser 184: 303-307

Tasker ML, Jones PH, Blake BF, Dixon TJ (1985) The marine distribution of the gannet Sula bassana in the North Sea. Bird Study 32:82-90

Votier SC, Bearhop S, Ratcliffe N, Furness RW (2001) Pellets as indicators of diet in great skuas. Bird Study 48:373-376

Votier SC, Furness RW, Bearhop S, Crane JE and others (2004a) Changes in fisheries discard rates and seabird communities. Nature 427:727-730

Votier SC, Bearhop S, Ratcliffe N, Phillips RA, Furness RW (2004b) Predation by great skuas at a large seabird colony. J Appl Ecol 41:1117-1128

Votier SC, Bearhop S, Ratcliffe N, Furness RW (2004c) Reproductive consequences for great skuas specializing as seabird predators. Condor 106:275-287

Votier SC, Bearhop S, Crane JE, Arcos JM, Furness RW (2007) Seabird predation by great skuas - intra-specific competition for food? J Avian Biol 38:234-246

Votier SC, Heubeck M, Furness RW (2008) Using inter-colony variation in demographic parameters to assess the impact of skua predation on seabird populations. Ibis 150(Suppl 1): 45-53

Witt MJ, Godley BJ (2007) Towards seascape scale conservation: using vessel monitoring systems (VMS) to map fishing activity. PLoS One 2(10):e1111

Wunderle JM Jr (1991) Age-specific foraging proficiency in birds. In: Power DW (ed) Current ornithology, Vol 8. Plenum Press, London, p 273-324

Zeller D, Pauly D (2005) Good news, bad news: global fisheries discards are declining, but so are total catches. Fish Fish 6:156-159

Submitted: February 14, 2008; Accepted: June 18, 2008

Proofs received from author(s): September 4, 2008 